\title{
Diterpenoids from the genus IIlicium and Their Bioactivities
}

\author{
Yingying $\mathrm{Fu}^{a}{ }^{a}$ Junyan $\mathrm{Chu},{ }^{a}$ and Jifeng Liu ${ }^{*, a, b}$ \\ ${ }^{a}$ School of Pharmaceutical Sciences, Institute of Drug Discovery and Development, Key Laboratory of \\ Advanced Pharmaceutical Technology, Ministry of Education of China, Zhengzhou University, \\ Zhengzhou, Henan 450001, China \\ ${ }^{b}$ Collaborative Innovation Center of New Drug Research and Safety Evaluation, Zhengzhou, \\ Henan 450001, China \\ Email: liujf2009y@126.com (J. L.)
}

\begin{abstract}
Diterpenoids are important chemical constituents isolated from the genus Illicium, which possess many pharmacological effects such as anti-inflammatory, antiviral activities, cytotoxicity, and so on. Up to now, 68 diterpenoids have been isolated from the genus Illicium, and they are classified as abietane-type, pimarane-type and podocarpane-type. In this paper, the chemical constituents and bioactivities of the diterpenoids from the genus Illicium are reviewed.
\end{abstract}

Keywords Illicium, diterpenoids, abietane-type, bioactivities

\section{Introduction}

The genus Illicium (family Illiciaceae) contains nearly 50 species worldwide, which mainly is distributed in east and southeast Asia. There are 28 species and 2 varieties in the genus that primarily are distributed in southern regions of China. The plants in this genus can be shrub or small tree, and they have the smell of fragrance. ${ }^{[1]}$ However, many plants of the genus Illicium are considered toxic. Its bark and fruit often are used as folk medicine to treat cough, rheumatism, lumbar muscle strain, skin inflammation, and cancer in ancient China. ${ }^{[2]}$ Previous phytochemical investigations on this genus have resulted in the isolation of some diterpenoids with anti-inflammatory, antiviral activities, cytotoxicity. ${ }^{[3]}$ Thus, the Illicium species have attracted widespread attention in recent years. About 68 diterpenoids have been isolated from the genus Illicium. Diterpenoids can be categorized into abietane-type, pimarane-type, and podocarpane-type. Among them, abietane-type diterpenoids are the primary type. Herein, we summarize chemical constituents and pharmacological effects of diterpenoids from the genus Illicium.

\section{Different Types of Diterpenoids}

Up to date, 68 diterpenoids have been found in many plants of this genus, such as I. minwanense, I. majus, I. jiadifengpi, I. merrillianum, and so on. Chemical components of diterpenoids mainly contain abietane-type, pimarane-type, and podocarpane-type.

\section{Abietane-type diterpenoids}

Among these diterpenoids, 54 abietane-type diterpenoids have been isolated and identified. Yokoyama et al. ${ }^{[4]}$ obtained a new abietane-type diterpene from a methanol extract of the pericarps of $I$. minwanense, named (+)-8,11,13,15-abietatetraene (1). From the twigs and leaves of $I$. majus. Fang et al. ${ }^{[5]}$ found four new diterpenes, named majusanic acid $A-D(2-5)$, and majusanic acid $B$ exhibited significant anti-inflammatory activity. From the roots of $I$. jiadifengpi. Zhang et al.$^{[6]}$ obtained nine new diterpenes, named jiadifenoic acid $A-G(6-12)$. Among them, jiadifenoic acid $A$ is a novel dimeric diterpene with a rare spiro[bicyclo[2.2.2]-oct-5-ene-2,10-cyclopentan]-3-one, and jiadifenoic acid B exhibited significant antiviral activities against Coxsackie virus B. From the fruits of I. wardii, Gao et al. ${ }^{[7]}$ purified two novel abietane diterpenes, wardinol A (13) and wardinol B (14) by intensive spectroscopic analysis. From ethanol extract of branches and leaves of $I$. merrillianum, Tian et al. ${ }^{[8]}$ isolated three new diterpenes, merrilliadione (15),

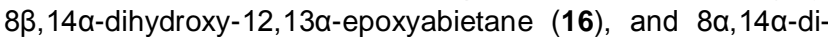
hydroxy-9,13ß-epoxyabietane (17). Compound 15 has a unique isopropyl $(13 \rightarrow 11)$-abeo-9,11-seco-abietane skeleton, which displayed moderate cytotoxicity against human cancer cells. From the aerial parts of $I$. angustisepalum, Sy et al. ${ }^{[9]}$ obtained twelve novel diterpenes, angustanoic acid $A(18)$, angustanal (19), angustanoic acid B (20), 4-epi-palustric acid-9a,13a-endoperoxide (21), angustanoic acid $\mathrm{C}-\mathrm{F}(\mathbf{2 2}-\mathbf{2 5})$, angustanol (26), and angustanoic acid G-I (27-29). Wang et al. ${ }^{[10]}$ isolated compounds, majusanic acid $E(\mathbf{3 0})$, majusanic acid $F$ (31), and majusanic acid $\mathrm{A}-\mathrm{C}(\mathbf{3 2}-34)$ from the roots of $I$. majus. Zhang et al..$^{[11]}$ found jiadifenoic acid $J-L(35-37)$ from the stems of $I$. jiadifengpi. Huang et al. ${ }^{[12]}$ isolated and identified 4-epi-dehydroabietic acid (38), 4-epi-abietic acid (39) and $8,11,13,15$-abietatetraen-19-oic acid (40) from the bark of $I$. jiadifeng. In addition, lambertic acid (41) was afforded from the roots of $I$. majus. ${ }^{[13]}$ From the twigs and leaves of $I$. Majus, majusanicol (42) was obtained. ${ }^{[14]}$ Besides, twelve known compounds from the genus Illicium have been isolated and identified as 7-hydroxy-1,4a-dimethyl-1,2,3,4,4a,9,10,10aoctahydro-phena-nthrene-1-carboxylic acid (43), 7a-hydroxycal litrisic acid (44), 12-hyrdoxydehydro-abietic acid (45), 15-oxo-17-norabieta-8,11,13-trien-18-oic acid (46), dehydroabietic acid (47), dehydroabietinol (48), 8,11,13-abietatrien-15-ol (49), aquilarabietic acid $\mathrm{J}(50)$, epipalustric acid (51), 4-epi-7a,15-dihydroxydehydroabietic acid (52), methyl abieta-8,11,13,15-tetraen-18-oate (53), and methy-16-nor-15oxodehy-droabietate $(\mathbf{5 4}) \cdot{ }^{[5-9,11,15]}$ Their chemical structures are shown in Figure 1.

\section{Pimarane-type diterpenoids}

In addition to abietane-type diterpenoids, pimarane-type diterpenoid was also found in this genus. Six pimarane-type 


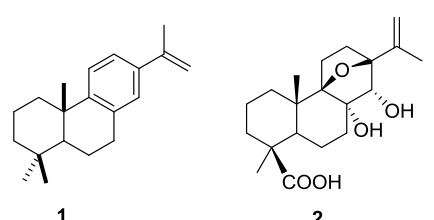<smiles>CC(O)C1CCC2Cc3ccc(C(O)O)cc3CC21</smiles><smiles>CC(C)(C)c1ccc2c(c1)CC1CCCC(C(=O)O)C21</smiles>

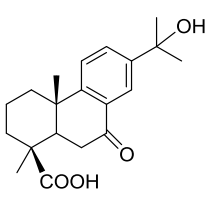

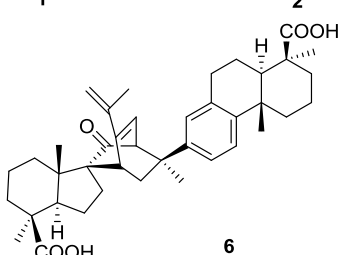

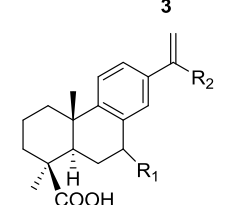

$\begin{array}{ll}7 \mathrm{R}_{1}=\alpha-\mathrm{OH} & \mathrm{R}_{2}=\mathrm{CH}_{3} \\ 8 \mathrm{R}_{1}=\mathrm{H} & \mathrm{R}_{2}=\mathrm{CH}_{2} \mathrm{OH}\end{array}$<smiles>CC(=O)c1ccc2c(c1)C(O)C[C@]1(C)CCC[C@](C)(C(=O)O)[C@]21C</smiles>

5

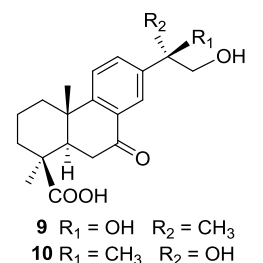<smiles>CC(C)[C@]1(O)CCC2=C(CC[C@@H]3[C@@H](C)CCC[C@]23C)[C@@H]1O</smiles>
$10 \mathrm{R}_{1}=\mathrm{CH}_{3} \quad \mathrm{R}_{2}=\mathrm{OH}$

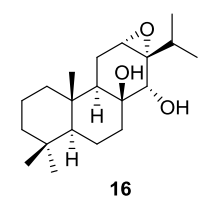

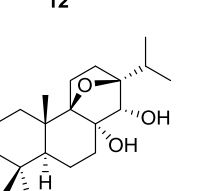<smiles>CC(C)c1ccc2c(c1)CC[C@H]1[C@H](C)[C@H](O)CCC[C@]1(C)O2</smiles><smiles>CC(C)[C@H]1C(=O)C2=C(C[C@H](O)[C@@H]1C)[C@@]1(C)CCC[C@@H](C)[C@H]1CC2</smiles><smiles>CC(C)C(=O)CCC(=O)C1=CC2(C)CCCC(C)(C)[C@H]2CC1</smiles>

15

16

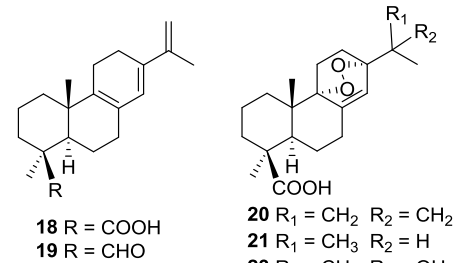<smiles>C=C(C)C12C=CC3(C)OC1(CCC3C1CCC[C@@H](C)[C@]1(C)C(=O)O)CC2</smiles><smiles>C[C@H]1CCCC2(C)c3ccc(C(C)(C)O)cc3CCC12</smiles><smiles>[R]C([R])(C)c1ccc2c(c1)CC[C@H]1[C@H](C)CCC[C@]21C</smiles>

今 $\overline{\mathrm{COOH}}$

$24 \mathrm{R}_{1}=\mathrm{CH}_{2} \quad \mathrm{R}_{2}=\mathrm{CH}_{2}$

$25 \mathrm{R}_{1}=\mathrm{CH}_{3} \mathrm{R}_{2}=\mathrm{OH}$ $27 \mathrm{R}_{1}, \mathrm{R}_{2}=\mathrm{O}$

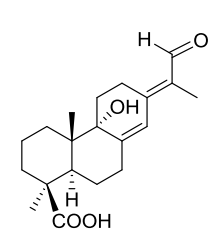

$23 \mathrm{R}_{1}=\mathrm{CH}_{3} \mathrm{R}_{2}=\mathrm{OH}$

22

26<smiles>CC1(C)CCCc2ccc(C(C)(C)O)cc2C1=O</smiles>

28

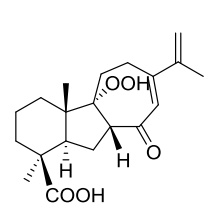<smiles>[R]CC(C)(C)c1ccc2c(c1)CC[C@@H]1[C@@](C)(C(=O)O)CCC[C@]21C</smiles>

$30 \mathrm{R}=\mathrm{OH} 15 \mathrm{~S}$ $31 \mathrm{R}=\mathrm{OH} 15 R$<smiles>[R]C1(C)CCCC2(C)c3ccc(C(C)(C)CO)cc3CCC12</smiles><smiles>C[C@@H]1CCCC2(C)c3ccc(C(C)(O)CO)cc3CCC12</smiles>

29<smiles>CC(=O)c1ccc2c(c1)C(=O)CC1[C@@](C)(C(=O)O)CCC[C@]21C</smiles>
$33 \mathrm{R}=\mathrm{CH}_{2} \mathrm{OH} 15 \mathrm{R}$

34

35<smiles>CC(C)c1ccc(C2(C)CCCC(C(=O)O)C2)cc1</smiles>

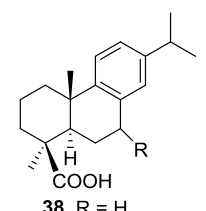<smiles>CC(C)C1CCC2CC3CCC(C(=O)O)CC3CC2C1</smiles>

36<smiles>Cc1ccc(C(C)C)cc1CC(C)C</smiles>

$45 \mathrm{R}=\mathrm{OH}$ $45 \mathrm{R}=\mathrm{OH}$
$47 \mathrm{R}=\mathrm{H}$

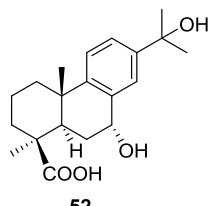

52<smiles>C=C(C)c1ccc2c(c1)CC(C)C(C(C)C)C2</smiles><smiles>CC(C)c1cc2c(cc1O)CC1CCCC(C)(C)C21</smiles>

40<smiles>CC(=O)c1ccc2c(c1)CC[C@@H]1[C@@](C)(C(=O)O)CCC[C@]21C</smiles><smiles>[R]C(C)(C)c1ccc2c(c1)CC[C@]1([R1])C(C)(C)CCC[C@@]21C</smiles>

$48 \mathrm{R}_{1}=\mathrm{CH}_{2} \mathrm{OH} \mathrm{R}_{2}=\mathrm{H}$ $49 \mathrm{R}_{1}=\mathrm{CH}_{3} \quad \mathrm{R}_{2}=\mathrm{OH}$

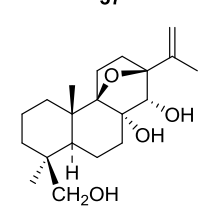

42

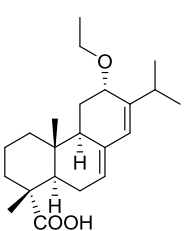

50<smiles>CC1(C)CCCC12c1ccc(O)cc1CCC2(C)C(=O)O</smiles>

43<smiles>CC(C)C1=CC2=C(CC1)[C@@]1(C)CCC[C@](C)(C(=O)O)[C@H]1CC2</smiles>

51

Figure 1 Chemical structures of abietane-type diterpenoids isolated from the genus Illicium. 
diterpenoids ${ }^{[6,9,11,12,15]}$ have been isolated and identified from the genus Illicium, named as jiadifenoic acid M (55), jiadifenoic acid $\mathrm{N}(56)$, 4-epi-sandaracopimaric acid (57), 4-epi-isopimaric acid (58), wulingzhic acid V (59), and isopimara-7,15-dien-19-ol (60), respectively. Among the compounds mentioned above, jiadifenoic acid $M$ (55) exhibited reasonable activity against CVB3 (Coxsackie virus B3). Their chemical structures are shown in Figure 2.<smiles>C=C[C@]1(C)CCC2=C(C1=O)[C@@H](O)C[C@H]1[C@@](C)(C(=O)O)CCC[C@]21C</smiles>

55<smiles>C=C[C@]1(C)CCC2=CC[C@H]3[C@](C)(C(=O)O)CCC[C@]3(C)[C@H]2C1</smiles>

58<smiles>C=C[C@]1(C)C=C2CC[C@]3(C(=O)O)[C@@H](C)CCC[C@]3(C)C2CC[C@]1(C)CO</smiles>

56<smiles>CC1(C(=O)O)CCC2C(=CCC3C2CC[C@H](O)C3(C)C)C1</smiles>

59
57<smiles>C=C[C@]1(C)CC[C@H]2C(=CC[C@@H]3[C@@](C)(CO)CCC[C@]32C)C1</smiles>

60
Figure 2 Chemical structures of pimarane-type diterpenoids isolated from the genus Illicium.

\section{Podocarpane-type diterpenoids}

Six podocarpane-type diterpenoids ${ }^{[5,6,11]}$ were found, named jiadifenoic acid $\mathrm{H}(6 \mathbf{6 1})$, jiadifenoic acid I (62), jiadifenoic acid $\mathrm{O}$ (63), jiadifenoic acid P (64), (+)-13-methoxypodocarpa8,11,13-trien-19-oic acid (65), and 13-oxopodocarp-8(14)-en19-oic acid (66). Among them, jiadifenoic acid $P$ exhibited reasonable activity against CVB3. Their chemical structures are shown in Figure 3.<smiles>[R]C1=CC(=O)CC[C@]12CC[C@]1(C)[C@@H](C(=O)O)CCC[C@]1(C)O2</smiles>

$61 \mathrm{R}=\alpha-\mathrm{OH}$ $62 \mathrm{R}=\mathrm{H}$<smiles>COc1ccc2c(c1)CC[C@@H]1[C@@](C)(C(=O)O)CCC[C@@]21C</smiles>

65<smiles>CC1(C(=O)O)C[C@H](O)c2cc(Cl)ccc2[C@]1(C)CCCO</smiles>

63<smiles>CC12CCC[C@@](C)(C(=O)O)C1CCC1=C2CC[C@H](O)C1=O</smiles>

64
Figure 3 Chemical structures of podocarpane-type diterpenoids isolated from the genus Illicium.

\section{Diterpene glycosides}

From the ethanol extract of $I$. brevistylum (Illiciaceae). Chen et al. ${ }^{[16]}$ identified two new diterpene glycosides, brevistylumside A (67) and brevistylumside B (68). Their chemical structures are shown in Figure 4.

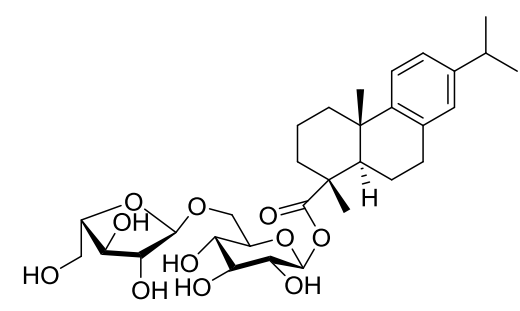

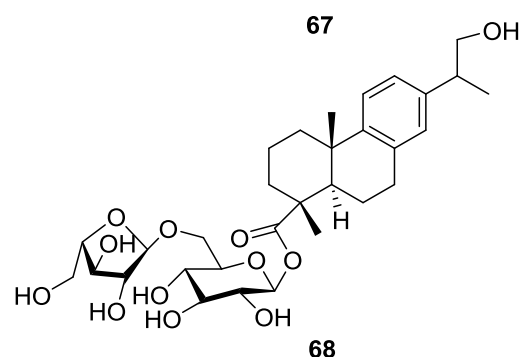

Figure 4 Chemical structures of diterpenes glycosides isolated from the genus Illicium.

\section{Bioactivities of Diterpenoids from the genus Illicium}

Diterpenoids from the genus Illicium have various pharmacological effects such as anti-inflammatory, antiviral activities and cytotoxicity.

\section{Anti-inflammatory activity}

Majusanic acid $B(3)$ inhibited the $\beta$-glucuronidase release in rat PMNs induced by PAF $\left(\mathrm{IC}_{50}=0.26 \pm 0.03 \mu \mathrm{M}\right)$, which is about 10 times higher than that of ginkgolide $\mathrm{B}^{[5]}\left(\mathrm{IC}_{50}=2.91 \pm\right.$ $0.47 \mu \mathrm{M})$. Compounds 8,11,13,15-abietatetraen-19-oic acid (40), methyl-16-nor-15-oxodehydroabietate (54), and 12-hydroxydehydroabietic acid (45) have strong NF-KB inhibitory activity, which can reduce LPS-induced 293-NF-kB-luc fluorescence intensity, ${ }^{[19]}$ indicating that abietane-type diterpenes are the main anti-inflammatory ingredient from $l$. brevistylum. Compound methylabieta-8,11,13,15-tetraen-18-oate $(53)^{[15]}$ shows good anti-inflammatory activity. Chen ${ }^{[15]}$ found that the total extracts of $I$. brevistylum and all extracts parts have good NF-kB inflammation inhibitory effect.

\section{Antiviral activity}

In recent years, many diseases were caused by virus infection, which had been a worldwide problem. Thus, it is urgent to find new antiviral drugs. Jiadifenoic acid B (7), jiadifenoic acid C (8), and 7a-hydroxycallitrisic acid (44) exhibited significant antiviral activities against Coxsackie virus B (RNA virus), which was the first report of diterpenes with anti-Coxsackie virus activity. ${ }^{[6]}$ It can be clearly seen from the above reports, abietane-type diterpenoids are the main chemical constituents against Coxsackie virus B, providing potential anti-Coxsackie virus drugs in the future. Majusanic acid $E(30)$, majusanic acid $F(31)$, 4-epi-dehydroabietic acid (38), majusanic acid $B(\mathbf{3 3})$, and majusanic acid $D(5)$ displayed moderate antiviral activity against the Coxsackie virus B3 with $\mathrm{IC}_{50}$ values of $3.3-51.7 \mu \mathrm{M} \cdot{ }^{[5,10,12]}$ Jiadifenoic acid $\mathrm{M}(\mathbf{5 5})$, jiadifenoic acid $N$ (56), jiadifenoic acid $P(64)$ and 13-oxopodocarp-8(14)-en-19-oic acid (66) exhibited reasonable activity against CVB3 with $\mathrm{IC}_{50}$ values of $7.0-22.2 \mu \mathrm{M}$ and selective index values $\left(\mathrm{SI}=\mathrm{TC}_{50} / \mathrm{IC}_{50}\right)$ of $49.3,37.1,31.3$, and $40.9,{ }^{[11]}$ respectively.

\section{Cytotoxicity}

According to the previous reports, few diterpenoids in this 
genus exhibited cytotoxicity. Tian et al. ${ }^{[8]}$ reported that

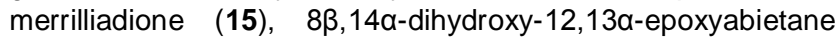

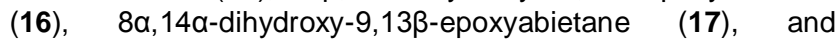
dehydroabietinol (47) displayed moderate cytotoxicity against A549, HCT116, MDA-MB-231, and BEL-7404 cell lines with $\mathrm{IC}_{50}$ values of $9.04-31.81 \mu \mathrm{M}$.

\section{Other bioactivities}

Li et al. ${ }^{[17]}$ found that the crude extract of $I$. lanceolatum has antimicrobial activity. De et al. ${ }^{[18]}$ studied the antimicrobial properties of star anise ( $I$. verum). The results indicated some compounds isolated from star anise can inhibit the bacterial growth.

\section{Conclusion and Perspective}

The plants from the genus Illicium have widespread medicinal values. Many chemical constituents have been isolated and identified by spectroscopic analysis and chemical methods. In this paper, we reviewed the main diterpenoids from the genus Illicium, including abietane-type, pimarane-type, and podocarpane-type. Some of them possess pharmacological effects such as anti-inflammatory, antiviral activity, and cytotoxicity. At present, researchers have studied many plants from the genus Illicium. Some new chemical constituents and bioactivities are being found, which will offer better medicinal values for clinical application in future. However, in-depth investigations on the bioactive mechanism are rarely reported in modern researches, and they should be strengthened on this aspect.

\section{Acknowledgement}

This work was supported by the Science and Technology Tackling Project of Henan Science Technology Department (No. 182102310063), the Key Scientific Research Project in University of Henan Province (No. 17A350013), and the National Natural Science Foundation of China (No. 81673322, U1904136)

\section{Conflict of Interest}

The authors declare no conflict of interest.

Copyright ( 2020 Yingying Fu, Junyan Chu, Jifeng Liu. This article is an open access article distributed under the terms and conditions of the Creative Commons Attribution (CC BY) license (http://creativecommons.org/licenses/by/4.0/). The use, distribution or reproduction in other forums is permitted, provided the original author(s) or licensor are credited and that the original publication in this journal is cited, in accordance with accepted academic practice. No use, distribution or reproduction is permitted which does not comply with these terms.

\section{References}

[1] Richard, M. K.; Saunders, F. L. S. Systematics of the genus Illicium L. (Illiciaceae) in Malesia. Bot. J. Linn. Soc. 1995, 117, 333-352.

[2] Zhao, L. Q.; Luo, Y. M. The terpenoids and their chemotaxonomic significance in Illicium. Guangxi Zhiwu 2007, 27, 272-276.

[3] Fukuyama, Y.; Shida, N.; Kodama, M. Isodunnianin: a new sesquiterpene enhancing neurite outgrowth in primary culture of fetal rat cerebral hemisphere from Illicium tashiroi. Plant Med. 1993,
$59,181-182$

[4] Yokoyama, R.; Huang, J. M.; Hosoda, A.; Kino, K.; Yang, C. S.; Fujiyama, Y. Seco-prezizaane-type sesquiterpenes and an abietane-type diterpene from Illicium minwanense. J. Nat. Prod. 2003, 66, 799-803.

[5] Fang, Z. F.; Zhang, G. J.; Chen, H.; Bai, J.; Yu, S. S.; Liu, Y.; Wang, W. J.; Ma, S. G.; Qu, J.; Xu, S. Diterpenoids and sesquiterpenoids from the twigs and leaves of Illicium majus. Plant Med. 2013 $79,142-149$.

[6] Zhang, G. J.; Li, Y. H.; Jing, J. D.; Yu, S. S.; Qu, J.; Ma, S. G.; Liu, Y. B.; Yu, D. Q. Anti-Coxsackie virus $B$ diterpenes from the roots of Illicium jiadifengpi. Tetrahedron 2013, 69, 1017-1023.

[7] Gao, Y. P.; Shen, Y. H.; Zhang, W. D. Two novel abietane diterpenoids from Illicium wardii A.C.Sm. Helv. Chim. Acta 2014, 97, 122-127.

[8] Tian, X. H.; Yue, R. C.; Zhang, S. D.; Shen, Y. H.; Ye, J.; Shan, L.; Li, H. L.; Wen, B.; Xu, X. K.; Zhang, W. D. Merrilliadione - a rare isopropyl (13 $\rightarrow 11$ )-abeo-9,11-seco abietane diterpene from Illicium merrillianum. Eur. J. Org. Chem. 2014, 2014, 4753-4758.

[9] Sy, L. K.; Brown, G. D. Abietane diterpenes from Illicium angustisepalum. J. Nat. Prod. 1998, 61, 907-912.

[10] Wang, Y. D.; Zhang, G. J.; Qu, J.; Li, Y. H.; Jing, J. D.; Liu, Y. B.; Ma, S. G.; Li, Y.; Lv, H. N.; Yu, S. S. Diterpenoids and sesquiterpenoids from the roots of Illicium majus. J. Nat. Prod. 2013, 76, 1976-1983.

[11] Zhang, G. J.; Li, Y. H.; Jing, J. D.; Yu, S. S.; Wang, X. J.; Zhuang, P. Y.; Zhang, Y.; Qu, J.; Ma, S. G.; Li, Y.; Liu, Y. B.; Yu, D. Q. Diterpenes and sesquiterpenes with anti-Coxsackie virus B3 activity from the stems of Illicium jiadifengpi. Tetrahedron 2014, 70, 4494-4499.

[12] Huang, P.; Gloria, K.; Peter G, W. Abietane diterpene acids from the bark of Illicium jiadifengpi. Nat. Prod. Res. Dev. 2005, 3, 309-312.

[13] Li, C. T. Ph.D. Dissertation, Anti-inflammatory constituents from three plants of genus Illicium and their chemotaxonomic significance. The Second Military Medical University, Shanghai, China, 2014.

[14] Fang, Z. F.; Liu, X.; Zhang, L.; Zhang, T. A new abietane type diterpenoid from the twigs and leaves of Illicium majus Hoot et Thoms. Chin. Pharm. J. 2016, 51, 2009-2012.

[15] Chen, C. M.S. Dissertation, Study on the chemical constituents from stem bark of Illicium brevistylum A.C.Smith and the anti-inflammatory activity. The Second Military Medical University, Shanghai, China, 2013.

[16] Chen, Y. H.; Dong, Z. Y.; Huang, D. D.; Chen, W. S.; Yao, F. Y.; Xue, Y. D.; Sun, L. N. Brevistylumsides A and B, diterpene glycosides from Illicium brevistylum. Phytochem. Lett. 2015, 14, 27-30.

[17] Li, H. J.; Li, H. R.; Wang, X. L.; Pei, Y. L.; Fan, G. Y. Study on the antibacterial activity of plants of the genus Illicium. Heilongjiang Xumu Shouyi 2016, 12, 178-180.

[18] De, M.; De, A. K.; Sen, P.; Banerjee, A. B. Antimicrobial properties of star anise (Illicium verum Hook f). Phytother. Res. 2002, 16, 94-95.

[19] Chen, W.; Lv, S. S.; Wang, X.; Chen, C.; Sun, L. N. Diterpenes from Illicium brevistylum and their anti-inflammatory activities. Zhongchengyao 2019, 41, 97-101.

Received April 16, 2020 Accepted April 30, 2020 